\title{
Sex, genes and stereotypes
}

\section{Steven Rose}

The Sexual Brain. By Simon LeVay. MIT Press: 1993. Pp. 168. \$22.50, £14.95. UK publication date, 1 July.

SIMON LeVay is a neuroanatomist whose early research, with David Hubel and Torsten Wiesel at Harvard Medical School, on neural plasticity in the visual system attracted considerable notice within the neuroscience community. But in 1991 , by then at the Salk Institute, he sprang to much wider fame with a paper in Science in which, on the basis of the morphometric analysis of brains from a sample of 19 declared homosexual male AIDS victims, 16 presumed heterosexual men and 6 presumed heterosexual women, he reported that the size of a nucleus in the medial preoptic region of the hypothalamus varied with sexual orientation among the men.

"Gay brains" immediately joined "gay genes" as the focus for intense debate both in the straight popular press (the New York Times, Time and Newsweek included) and in the gay community itself*. It is far from irrelevant in this context that LeVay himself is a declared gay, for the issues raised by the question of the possible biological origins of differences in sexual orientation seem to differ from those posed by other examples of biological determinism, of genes 'for' violence, criminality or differences in IQ scores between ethnic groups. The difference lies not so much in the nature of the logical chain supposed to link a particular biological measure with a particular behaviour or character trait, for this presents similar complexities in each case, but in the responses to the deterministic claim. Significant sections of the gay community have actively welcomed the LeVay report, regarding it as demonstrating that gays are indeed biologically different and should therefore be neither morally stigmatized nor socially penalized. If gays are born, not made, as one gay activist has put it to me, then parents can relax; gay schoolteachers are not going to be able to corrupt the morals of otherwise heterosexual children. Other gays have been vehemently critical of any such suggestion of biology as destiny.

The Sexual Brain begins with a brief trip through current thinking on the biology, evolution and development of sex, with an overview of the neural mechanics of copulation, before focusing on its main agenda, the biological and, above all, the

* See also the leading News and Views article, "I homosexuality hard-wired?" (Nature 353, 13; 1991). brain determinants of sexual activity and orientation. Unsurprisingly, the book culminates in a discussion of LeVay's own findings and recent twin studies and their implications for understanding the nature and origins of homosexuality (mainly male; lesbianism is mentioned briefly though it doesn't even merit an index

\section{IMAGE UNAVAILABLE FOR COPYRIGHT REASONS}

\section{Homosexuality — born or bred?}

entry) and transsexuality. The book's pleasingly informal style marks it as being intended for a wide audience, which its theme and author's reputation will undoubtedly ensure, although anyone unfamiliar with brain structures will find it hard going in places, not least because, astonishingly for a book written by an anatomist, it relies entirely on verbal description, with not a single diagram or photograph to help the uninitiated through neuroscience's dog-Latin.

LeVay's own data and the related genetic claims have been subject to intense critical scrutiny over the past couple of years (in, for instance, Anne FaustoSterling's Myths of Gender (Basic Books, 1992) and Ruth Hubbard and Elijah Wald's Exploding the Gene Myth (Beacon, 1993)). Without citing his critics directly, LeVay carefully acknowledges some of the interpretative problems his observations present. But he is much less cautious - and this is a really worrying feature of a book intended for a wide audience - in accepting the data and claims of others that seem to support the thrust of his argument. His goal is clear: to rebut what he sees as a "Freudian" or psychologistic account of the origins of homosexuality which root it in early childhood experience and to replace it with a biologistic alternative. Fancy, for LeVay (who has a penchant for Shakespearian epigrams to head his chapters), is clearly bred in the head - if not the genes. To this end he cheerfully extrapolates from rats to humans and sweeps together a mélange of distinctly dubious ancedotal and anthropological data and sociobiological speculations, from stories of young twins playing naked in the woods so that they might attract homosexually inclined truck drivers to molest them, to E. O. Wilson's bizarre fantasy that 'gay genes' could have adaptive value (if, despite presumably diminishing the number of offspring their possessors might leave, they also predispose towards assisting in the rearing of siblings' offspring). To LeVay, it ․․․ seems, everything in this mix is of 产 equal evidential weight.

But the sharpest problem, to my mind, is the way in which his approach reifies homosexuality and needlessly polarizes 'social' and 'biological' causation. He frequently argues as if 'homosexuality' and 'heterosexuality' were fixed properties of an individual rather than descriptors of parts of a continuum of developmentally expressed polyvalent sexual behaviour and activity that vary during any individual's lifetime and have ascribed social and cultural meanings that differ widely from age to age and society to society. I, for one, find it difficult to believe that being homosexual in San Francisco today has the same meaning for an individual, either biologically or socially, as it might have done in Victorian England. To be sure, LeVay nods in this interactionist directon, as in his closing words: "Like waterlilies, we swing to and fro with the currents of life, yet our roots moor us each to our own spot on the river's floor." This is a distinctly more agreeable image than Wilson's of genes holding culture on a long leash, but the dominant motif remains that of fixity, rootedness, over which the social currents gently wash. Yet in an earlier incarnation LeVay would not, I suspect, have chosen this image to delimit the richness of his own findings in the much less complex field of the interplay of neural specificity and plasticity. of ontogenetic experience, in shaping the cellular responses of the developing visual cortex. Understanding the origins and significance of our own sexuality and sexual preferences will require at least as careful an integration of theory, experiment and observation as does interpreting the visual system of the cat.

Steven Rose is in the Brain and Behaviour Research Group. Open University. Milton Keynes MK7 6AA. UK. His most recent book. The Making of Memory (Bantam. 1992). has won this year's Rhône-Poulenc science book prize (see last week's issue). 